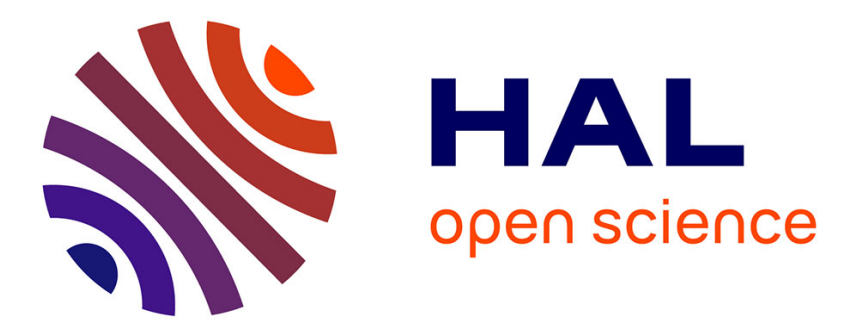

\title{
Citizen Advisory Committees: A Tool to Remedy the Shortcomings of the Contingent Valuation Method Within the System of Multi-Level Governance
}

\author{
Philippe Bance, Angélique Chassy
}

\section{- To cite this version:}

Philippe Bance, Angélique Chassy. Citizen Advisory Committees: A Tool to Remedy the Shortcomings of the Contingent Valuation Method Within the System of Multi-Level Governance. International Journal of Public Administration, 2019, 42 (8), pp.685-695. 10.1080/01900692.2018.1500586 . hal02910727

\section{HAL Id: hal-02910727 \\ https://hal.univ-antilles.fr/hal-02910727}

Submitted on 3 Aug 2020

HAL is a multi-disciplinary open access archive for the deposit and dissemination of scientific research documents, whether they are published or not. The documents may come from teaching and research institutions in France or abroad, or from public or private research centers.
L'archive ouverte pluridisciplinaire HAL, est destinée au dépôt et à la diffusion de documents scientifiques de niveau recherche, publiés ou non, émanant des établissements d'enseignement et de recherche français ou étrangers, des laboratoires publics ou privés. 
Citizen advisory committees:

\title{
a tool to remedy the shortcomings of the Contingent Valuation Method within the system of multi-level governance?
}

\author{
Philippe Bance and Angélique Chassy
}

Article

Citizen Advisory Committees: A Tool to Remedy the Shortcomings of the Contingent Valuation Method Within the System of Multi-Level Governance

Philippe Bance \& Angélique Chassy

$\underline{\text { International Journal of Public Administration }}$

Published Online: 06 Aug 2018 https://doi.org/10.1080/01900692.2018.1500586

\begin{abstract}
The Contingent Valuation Method (CVM) is an economic analysis tool used to measure, the utility of producing of public goods, based upon individual's declared preferences. The public decision-maker is thus able to arbitrate between the expenditure to be made. The approach has been deployed in a centralist conceptual plan, leaving little room for citizens in the decision-making process and it has been undermined by the rise in power, notably in Europe, of multi-level governance. The decision-maker is no longer alone in this process and public decision-making must operate on the basis of common views adopted by various levels of government that should also establish much stronger links with the citizen-users of public goods. This article analyzes the operational impact of Citizen Advisory Committees (CAC) as participative tools of CVM to resulting in an effective cooperation between the various public actors and the civil society in public decision-making.
\end{abstract}

Keywords: public management, citizen participation, multilevel governance, individual preferences, monetarisation, public decision

Code JEL : H - H41- H62 - D61 - D70 


\section{Introduction}

The $\mathrm{CVM}^{1}$ developed by The Welfare Economics of Public Policy (WEPP) aims to base public decision-making on the preferences revealed by citizen-consumers the production of public goods, using hypothetical scenarios administered for public decision-makers. Comparable to a public opinion survey carried out with the help of a predetermined questionnaire, the CVM is generally administered by interrogating a sample of individuals benefiting from the production of public goods in order to determine their willingness to pay. The aim is to know if it is advisable to create the service, maintain, remove or improve it based on the monetary value of the benefits that it is supposed to offer according to the individual benefits that it is supposed to provide, by comparing these benefits to the costs of producing them. In this way, the public policy maker can compare the net benefits of alternative programs and prioritise the services to provide in line with their stated social utility. However, there is controversy over the CVM; it has its supporters and detractors regarding the evaluation of public policies. The conceptual framework on which the CVM is based is the object of a number of methodological criticisms. Diamond and Hausman (1993) point out that hypothetical bias is the main problem of the method, by ensuring that the citizens-consumers interviewed do not give the right information. This methodological difficulty stems from a hypothetical situation in which individuals are generally unprepared. The hypothetical scenarios must lead citizen-consumers to express a monetary value. Portney (1994), however, considers that criticism of the CVM should not prevent it from continuing to play "a role in public policy formulation" (p.16).

He therefore advocates seeking to improve it, in particular in terms of how individual preferences are to be understood. This has prompted numerous studies to improve the reliability of the method, in particular on how surveys are conducted and the interpretation of willingness to pay or to accept by consumers (for example: Bonnieux, 1998; Clinch and Murphy, 2001; Ryan \& alii, 2001; Harrison, 2002; Flachaire and Hollard, 2005; Grappey, 2009). Hausman (2012) has nevertheless questioned theses studies. He states that the hypothetical situation in which interrogated citizen-consumers are placed renders their declared preferences unstable or ill-defined. Under these conditions, Hausman (2012) points the CVM is unreliable to provide good data and information for policimaking. However, Carson (2012) suggests a departure from the debates aimed at discrediting the method "to focus instead on making it better " (p.40). This article aims to show how the establishment of Citizen Advisory Committees (CACs) could significantly improve the reliability of the results obtained from the contingent evaluation in order to make better use of it in public decisionmaking.

However, our analysis, however, is based on a criticism about the centralist and littleoperative character of the CVM, placing it in an institutional context of multilevel governance, which is that of its concrete implementation especially in Europe. Indeed, the CVM framework shows the basis of its inspiration to be inherently centralist. It ensures one central public decision-maker is an omnipresent authority, who with full knowledge of the preferences of the citizen-consumers based upon information obtained thanks to CVM, is the

\footnotetext{
${ }^{1}$ The CVM developed under the influence of the federal government of the United States in the framework of an environmental policy and more particularly from the « Environment Protection Agency » inspired by the founding works of Ciriacy-Wantrop, 1947 ; Davis, 1963 ; Randall, Ives, \& Eastman, 1974 ; Mitchell \& Carson, 1989 ; Arrow \& Solow 1993 ; Diamond \& Hausman, 1993.
} 
guardian of the common interest. Yet this centralist idea is undermined by the distribution of multi-level governance and notably in Europe.

This is characterized by the fact that the state is no longer a sovereign hierarchical decisionmaking body, since it is located in a polycentric system comprising several supranational or local decision-making centers (Ostrom et al.1961). Public decision-makers are numerous and work jointly in decision-making in a context marked by «co-opetition », in other words characterised simultaneously by both competition and cooperation (Brandenberger and Nalebuff, 1996). Christiansen (1996) states that the essence of multi-level governance encompasses "non-hierarchical systems of political negotiation [and] regulation" (p.13) between different public decision-makers. This new system of governance is a source of potential by allowing the rapprochement of the decision-making process of citizens in applying the principle of subsidiarity which requires us to take decisions whenever needed and as close as possible to the citizen. But it is also at the root of the «transaction costs » tied to the interactions at work between decision makers to undertake public policy (Bance, 2016). This system of multi-level governance is thus a source of opportunity in the application of CVM by allowing public decision-makers within different levels of government to make it a tool for dialogue and negotiation in order to make collective decisions (Bance and Chassy, 2016). But within this multilevel, the CVM is nevertheless a method that does really into account of the opinions of citizens in the different stages of the decision-making process. This is in part due to the difficulty of citizens and decision-makers (in particular local) to correctly apply the method, the different levels of expertise of the stakeholders and the strong reservations held by them.

The purpose of this article is therefore to specify how the implementation of the CVM can be inspired by a participative approach involving more directly citizen-consumers in the decision-making process for producing public goods, and according to which methods and under which conditions. In the literature on the subject, the interaction between state and citizens for public decision-making is indeed a recurring question in multiple publications.

The JPART virtual issue analyses it, concerning the publications of the journal on the question of "citizens' perceptions, attitudes, experiences of, or behavior related to public administration" (Jacobsen et al. 2016). In the articles concerned, the place given to citizens remains secondary. The interaction between state and citizens is not considered as a central principle of organization of public action and the authors think it is necessary to analyze it more precisely. Furthermore, the role of citizens is never studied in the institutional framework of multilevel governance. By giving a different place to citizens in a multi-level decision-making process, we can remove certain methodological doubts about the CVM, and in particular remedy the hypothetical bias of which Hausman speaks. CACs have never been proposed as possibly associated with the CVM in this perspective. By their mobilization ex ante, in itinere and ex post into the evaluation process, CACs may make it possible to seek to rebuild the public decision on collective learning mobilizing citizens and multiple political decision-makers. Thus, in this article we analyse the influence of the establishment of CACs by an active role in a process of joint decision-making involving multi-level political makers and representatives of citizen - consumers. The CAC starts by clarifying how the system of multi-level governance radically changes the conditions for the implementation of the CVM. Thereafter on the basis of a critical analysis of the position in which the role of citizens in the decision-making process is limited by CVM, an analysis will be made of how CAC could address the low level of involvement by the citizens. 


\section{The impact of the system of multilevel-governance on CVM implementation in a Cost and Benefit Analysis (CBA) perspective}

Arbitrating effectively between public expenditure has become, with the implementation of the New Public Management (NPM), a major preoccupation of public authorities irrespective of their level of territorial jurisdiction.

The economic assessment of public action based on the measurement of its costs and benefits is in this way a tool allowing us to understand the citizens' expectations and to rationalise the funding of public expenditure. Political arbitration must rest on a relevant appreciation of citizens' preferences, in order to conduct a policy of supplying public goods, which are aligned with social needs. However, the large number of public decision makers in a system of multi-level governance, by definition characterised by numerous public authorities associated with decision taking to produce public goods, complicates this decision-making process, particularly because of insufficient forums for dialogue and negotiation. There are therefore new institutional devices of governance of public policies that it is appropriate to look to establish, in a the search for efficiency. In this perspective, can be re-examined the role of the CVM in public policy-making and implementation in a multi-level system.

\subsection{The use of the CVM in the multilevel system of governance}

The growing strength of a type of public management focussed on performance provides a favourable basis for ex ante economic evaluation and for considering the effectiveness of public policy. It is needed to prepare the ex ante arbitration of public measures ex ante, to anticipate the results of public investments when compared to the costs incurred and finally to assist with public decision-making. In this way, the evaluation process must guarantee a high level of citizen participation and transparency (Bourdin et al., 2004). The CBA is the reference tool of the standard economic analysis to check ex ante the costs and benefits of producing non-marketable public goods based on monetary values derived from individual preferences. The goal is to allocate resources in an efficient way by involving the different stakeholders in public policy: state, local and regional authorities, supranational decision makers, public service operators, in liaison with the citizens.

In order to "best" manage public, the state must act in unison with other stakeholders. This proves indispensable in the system of multi-level governance which is now especially prevalent across the European Union (EU) in line with the assertion of the idea of subsidiarity introduced by the Maastricht Treaty (1992) then recognised by the Lisbon Treaty (2009) as a fundamental principle of the Union. Subsidiarity favors decision-making level closest to the citizen to implement public policies in line with the latters'expectations. The aim is to give more autonomy to local councils so that citizens may be more involved in public decisionmaking. The gradual decentralisation of public policy-making is a new challenge for evaluation. With allocations to local councils being one of the state's largest expenses, the good governance of local policies, conducted in liaison with all the stakeholders, becomes vital. Local councils must be able to assist the state in defining and implementing public policies and in contributing to their funding. Hence, the evaluation is not limited to a single level of decision-making but to several. Such a process of taking into account multiple actors located at different institutional levels to evaluate public policies therefore adds of the complexity. Indeed, Damard and Roy (2000) state that stakeholders ofen have different value systems that pose challenges in reaching consensus.Multi-level governance is about ensuring better consideration of the interests of the people in local areas by granting the authorities powers that allow them to specify and implement public policy in an effective way in close relation with to the stakeholders (Bance, 2016). However, how does one solve what can be 
called the «contemporary crisis in public decision-making » which is characterised by the difficulty to involve simultaneously public decision-makers and citizens in shared and consensual decision-making. The characteristic traits of this crisis are notably highlighted by Bailly $(1998,13)$ :

- "We too often rush into a decision with or without prior negotiations...;

- "We move too quickly to negotiate or compromise without letting the debate buld up on the diagnosis, without always taking the time necessary for collective learning ...";

-"We mostly try to explain our decisions and to convince others rather than try to listen and work with the population and their representatives".

This crisis questions the ability of the CBA to participate in an approach that would proceed on an ethical plan to a search for transparency in the context of sound and effective management of public funds. This may lead to question the new evaluation processes that allow the implementation of a model new public management based upon the interaction between all the stakeholders. In this vein, Hassenteufel (2008) advocates to focus on individual interactions within a collective framework. In this regard, the CBA can contribute to the development of «reflexivity» between decision makers which can prove useful. CBA can promote the sharing of responsibilities between stakeholders to support effectiveness in public policy. Indeed, joint responsibility is an approach used to organise the participation of stakeholders. Sharing responsibility is a process that encourages stakeholders to find a common objective regarding a problem or to a clearly identified need. Achieving this objective relies on the consultation, which must be "both inclusive and differentiating from the views of all" (Damard and Roy, 2000, 6). Here, the citizen's opinion takes a crucial place. Drawing upon on the CBA of citizen-consumers, which translates the monetary equivalent of a change in usefulness to the individual, CBA informs, to all decision-makers, the state and local authorities, a knowledge of the most eagerly anticipated public expenditure by the citizens. But the CBA can also encourage or even trigger a cooperative attitude among in stakeholders to jointly build the policy-making process based upon a shared decision-making tool.

As will be seen further along, the utilisation CBA with other tools for considering the final decision to lead public policy, enables break with a top-down a decision-making process from thus subscribing to a shared-build approach by the different levels of public authorities in support of citizens' preferences. In this perspective, the CVM can be a tool allowing various public policy makers to make, in a coordinated way, based upon citizens' expectations.

The CVM can calculate the monetary value of non-market goods and services by using hypothetical scenarios. A scenario "represents the support of the exchange between " the seller $"$ of the goods (...) (the public or private decision-maker) and "his buyer" (society)" (Voltaire et al., 2011, 184). Here one identifies a willingness from consumers to pay (WTP) for public goods for their improvement or to avoid their degradation. One can also reason in the same way in terms of willingness to accept (WTA), of a sum payable to the individuals, to compensate them for the reduction or degradation of public goods and services. One "proceeds therefore from the value attached by individuals to the value for society by simple aggregation" (Meunier and Mardsen, 2009, 4) WTP or WTA. It is a question of determining, the social value of public goods on the basis of maximising individual utilities. In this perspective, public decision-making is based an arithmetic evaluation of the pleasures and pains of citizen-consumers. To uncover individual preferences, one undertakes public surveys using questionnaires addressed to citizens. These display present all the information on the public policy of which one seeks to define the value of WTP and they questionnaires are 
heavy complicated to administer. Here one determines the maximum amount the household would be ready to pay, for example, to finance an environmental program. The "fictitious price" thus obtained by aggregation allows the comparison of monetised benefits to the costs generated by a program in order to decide whether or not it shall be implemented.

If the result is positive, that is to say it provides a "social surplus", the program is socially desirable, therefore useful. Conversely $a$ "social deficit" shows that the program is not globally useful. On this basis, the public decision-maker can arbitrate between several public projects. It is here that one finds the possibility to apply the CVM to the system of multi-level governance: the information provided allows each of the policy makers to negotiate by comparing the projects and to choose the one that appears to be the most justifiable, accounting for financial constraints. The hypothetical scenarios proposed to the citizens in order to collect their preferences are a palliative instrument aimed at adressing the imperfect information in the context of public decision-making. Indeed, public decision-making often falls upon the elected representative. According to Delebarre (1998), public decision-making is delegated from the citizen to the elected representative, a fact that does not necessarily constrain the will of the politician to be transparent with the choices they makes.Yet a public decision-maker is not inclined to put in place a consultation that did not feature on any earlier electoral programs and the citizens already have expectations on the project submitted to their evaluation. But, with the public decision-makers who do not have to hand all of the information allowing them to make the right decisions, the CVM is a useful tool to legitimise which the public decisions must be made taken. This method professes to be democratic by taking into account ex ante the opinions of citizen-consumers in the decision-making process.

Indeed, the WTP of the individual can perhaps be considered as "the expression of a vote" which is going to weigh on the public choices in the negotiations within the different levels of government (Claeys-Mekdade and Vivien, 2003, 209). In this process, citizens respond to questionnaires and give their opinions. But, first, the evaluative approach does not sufficiently mobilise the citizens in the elaboration of the questionnaires and, second, it doesn't eiher take into account their opinion concerning the results obtained during decision-making.

\subsection{The place and the role of the citizen called into question in the use of the CVM in the multilevel system}

A multi-level decision-making process clearly aims to strengthen the link between public decision-making and citizens' preferences; but this is not done by a standard appeal to the CVM (Bance and Chassy, 2016). Considering that the different public decision-makers aspire to « better spend» by introducing a stronger and more democratic management to benefit of the citizens in a multi-level system, achieving of such an ambition requires an effective dialogue between decision-makers and citizens. Citizens must be able to express themselves freely and fully within the decision-making process, debate while exercising their right to disagree in the evaluation of public policies and without an arbitrary preference being given to any single point of view.

In the CVM's methodological framework of reference, the decision-makers are at the centre of the decision-making process and the citizen "appears as marginally as a recipient" (Fabre et al., 2003, 45) and therefore a simple object of public intervention. This idea should not be seen as the unique normative approach, especially in a multi-level system. One can identify in the CVM methodology three successive operating stages which are: the development of the questionnaire, the citizen's evaluation and the decision being made. The first stage "ex ante" does not traditionally involve citizens except in the form of pre-surveys in a pre-established framework, thus giving the peoplenlittle space for expression in the drafting of the 
questionnaire. It mainly involves public decision-makers who assess the public policies they judge, in need of an evaluation. In this perspective, a discussion between the different levels of government can firstly be conducted to evaluate the relevance of the policies co-financed by the joint decision-makers.

Having specified the public goods necessary to produce or preserve, a consultation can be organised between decision-makers as follows: questionnaires are developed jointly by the different levels of public authorities allowing them to define the methods as well as the content of the programs and of their evaluation. Why choose such a program? What type of hypothetical scenarios should be proposed to the citizens? This last question is crucial to make the scenarios comprehensible to the citizens. The authorities must then to draft the hypothetical scenarios which they consider them relevant for the questionnaires. The citizens' evaluation intervenes at the second operating stage "in itinere". The citizens (at least those who participate in the survey) are invited to participate in the evaluation by responding to a questionnaire and therefore express themselves freely through their CBA on the utility or pointlessness of the public policy. The third operating stage, "ex post", is that of the final decision. After based the citizens' responses, the public decision- makers communicate following the citizens' responses by analysing the effects (benefit or deficits) of the joint programmes and they indicate why the latter are justified or not with regards to the expectations of citizens, how to prioritise them and thus legitimise, a decision on the course of action to take. However, paradoxically, in this type of decision process, the citizenconsumers' preferences are frequently barely considered or strongly altered. The CVM sets participation practices where the citizen may be manipulated (Chassy, 2011). It is difficult to rally citizens in order to set up the prior development of hypothetical scenarios, particularly given that this step is based upon the concerns of multiple public decision-makers at different levels. The diversity of programmatic concerns from the various stakeholders already makes it difficult to specify the nature of the programs to evaluate, and what is at stake in each of them. Another is the difficulties the citizen may meet while trying to understand scenarios proposed by public decision-makers.

Indeed, from the start, each person does not have the same background in order to understand what is being asked of them. According to Bourdieu the contents of questionnaires are not always accessible to a large part of the population. Citizens have difficulties evaluating the collective interest when they are not directly affected by public policies. This calls into question the idea that the population has an opinion on all the topics proposed in the polls. (Blondiaux,1997). This amplifies the inherent difficulty with CVM, which is encouraging citizen-consumers to give their opinions on subjects they do not fully grasp. Also results obtained by WTP are skewed generating extreme amounts or null values. In this way, expected results from CBA can lead to making the wrong decisions. This approach is likely to make citizens lose interest and stop responding to questionnaires or to respond in a way that is not relevant. Mignauw (2016) specifies, in this sense, that: "opposition can be not only to the purpose of the project but also to its design, its content and the terms of its realisation" (p. 208). But opposition can also be directed at the final decision. Citizens are indeed mostly absent from the complicated, final arbitration between the various public decision-makers. Furthermore, the decision-makers who are "the farthest from the citizens" are those who, from a distance, exhibit the highest technical expertise and mastery of the CVM. This situation often leads the decision-maker evaluators to consider themselves omniscient and to act as if they had all of the information, which may provoke the reject of their decisions by the citizens: why was a given a project or another chosen and on what clear basis in view of its discrepancy with the results of the enquiry to the citizens? The absence of public debate is 
thereafter the source of serious questions regarding the choices made. However, if the final decision belongs to public decision-makers, the citizens may also participate in this decision, by their evaluation judgement (Milet, 2007).

Hopefully the choices made in the system of multi-level governance will not provoke, in an even worse capacity than in a one-level system, a deep misunderstanding regarding the decisions adopted due to a lack of final consultation. Effectively, citizens are confined to a passive role and the decisions made can be at great variance with from their preferences. In this context, the use of CVM limited to its traditional field of application is risky and even potentially perverse since if citizens no longer hold the same information or they find themselves too distanced from the subject, they risk being « robbed» by the final decision. This situation damages the citizens' confidence in decision-makers and is therefore the root of failure in the process of joint-construction between stakeholders. Let us then specify how the CAC would allow to associate citizens with the public decision-making process in a multilevel system.

\section{Towards a participatory approach mobilisating CACs in the framework of the CVM?}

By mobilising local decision-makers and the citizens around the CVM, one can seek to enrol them in the open space decision taken collaboratively. A correct application of the method is however subject to certain conditions, in particular to associating it with the citizens in a relevant way in order to bring credible information to the decision-makers. To do this, the hypothetical scenarios must be comprehensible to the citizens, reporting their preferences in a relevant way and explaining clearly their WTP for the production of public goods. In this context, citizens should nevertheless be actors to bring about change and innovations. This leads one to advocate the adoption of a methodology which supports a participative involvement from citizens and provides democratic legitimacy in the framework of multi-level governance.

\subsection{The advantages of a new participative approach based upon CACs}

It is necessary to look at reconsidering the utilisation of the CVM in the multi-level decision-making process by seeking to better inform and involve citizens in the different stages of the implementation of CVM. Informing the citizen-consumer in the best possible way "about the nature, depth, and economic significance of these values is particularly important for the supporters of CVM" (Portney,1994, 15). In line with a critical approach of this methodology, Portney reports that research needs to be focused on "cognitive processes, rationality, and the nature of preferences for all goods, public or private" (p. 15). The citizens' involvement resulting from the implementation of the CAC can thus improve the technical and social quality of the final decision taken by decision-makers. Consequently, to reinforce the joint-building of the decision-making process, and despite the latter's complexity of the decision-making process, the improvement of the participative approach should operate by associating citizens at each stage of the implementation of CVM and more particularly, ex ante and ex post, which is strongly lacking in the habitual terms. In cases of lack of understanding and of « compromise » achieved by the players for a shared decision at each of these stages, the loop of the participative approach will assuredly be left is unfinished.

One way to satisfy this ethical as well as socially acceptable principle of the public policy is to put in place "Citizens' Councils » endowed with their own means of actively participating in the evaluation, using their own expertise and communication (CEEP-CIRIEC, 2000). CAC's can have a real power of influence to act on decisions. The consultation "gives people affected by a decision the opportunity to influence or even change it" (Federation of Quebec Parents Committees, 2009, 10), by notably permitting them to observe, to propose, to 
advise and to amend. The CAC refers to the notion of participatory democracy by enabling citizens to be involved in the design and implementation of public decisions.

The CAC is generally made up of a wide audience of voluntary citizens from different backgrounds and cultures (young people, employed persons, retirees, etc.). The Committee may be constituted, at the request of the public decision-makers, of qualified but voluntary persons, such as local associations, but also of "persons and collectives furthest from the traditional concertation forums" (Reference framework - Citizens ' councils). Thus, the CACs are intended to be representative of the population. They can run for one or two years for a particular study need, over the term of a municipal mandate ( 5 or 6 years), or be permanently instituted for government organizations. The CAC is intended to be animated by a third party, who is a member elected by the Committee. The latter is accompanied by an elected representative considered to be "the municipal referent" and liaising with the other municipal officials. This type of consultation has been used in France through neighbourhood councils by local authorities and by federal institutions in the Canadian government for many years. So, the Canadian government introduced such opportunities for citizen participation in public security, and more precisely in the framework of a service described as "correctional". Impartial and quality democratic bodies were created to implement new policies or programmes by unbiaised advice and recommandations (Correctional Service, Canada).

The co-construction of the public decision-making process can be carried out through them by a continuum of volunteer citizens' involvement. This leads to "recognising citizens as "experts in their daily lives" (Sintomer, 2008, 121), through varied and complementary forms of dialogue that allow them to grasp the concept of use and non-use values of public goods. Knowledge in relation to use values is a skill acquired in the direct apprehension of the effects of public policies and the understanding of their nature. Knowledge related to non-use values are those of "laymans" who do not know the program but can nevertheless grasp the nature and scope of it by mobilizing the skills acquired in society.

The knowledge of use and non-use of the policies evaluated can be mutually enriched by discussions within CACs and with decision-makers: this can be used to apprehend social preferences, define the fields of intervention and political objectives to be pursued. A good operational implementation of CACs could have therefore as their objective the full consideration of citizens' needs and interests in the decision-making process with regard to production of public goods by multi-level public authorities.

\subsection{The application of CACs in the making process of the CVM}

At the ex ante stage of the process, the CAC could indeed underline and recognise citizens' preferences in order to identify the relevant public policies for evaluation and also to specify the contents of the hypothetical scenarios. They would prevent decision-makerevaluators from seeing themselves as omniscient and as guardians of all of the information. With regards to explaining in monetary terms the utility of a policy it is indeed fitting to have previously defined the project in qualitative terms in order to know if it responds to the needs of the citizens. With CACs, decision-makers benefit from a qualitative response about what citizens appreciate or dislike in matter of current public policy. Indeed, the aim of the participatory approach is to get people to share and develop a common project (Plottu and Plottu, 2009), while "the impact of cooperation can vary substantially across types of public goods" (Loeper, 2017, 192). This approach allows decision-makers to discuss and make preliminary choices while being aware of the citizens' preferences on the policies to evaluate. As it develops hypothetical scenarios, the interface of the CAC can aim to turn them into social constructs based upon on shared expertise. The participative approach proceeds 
towards this aim of dialogue in the development of hypothetical scenarios that are the basis of the questionnaires. At the stage ex ante, it is essential for the scenarios to be comprehensible and credible in order to avoid replies without significance (Terreaux and Brahic, 2009).

So, foasr their first objective, the CAC have to work with the decision-makers on the joint construction of the scenario by verifying that the questioning is relevant to the citizens. It also involves being certain that the different sensibilities and social, cultural and political practices of the citizens can be taken into account and that the vocabulary used does not hurt these sensibilities. The decision-makers can study with the members of the CAC any elements that may arise and render the scenarios inaccessible to the community. In addition, semantic and technical obstacles that prevent or limit mutual understanding must be removed. The decision-makers in particular have a better knowledge than the citizens of the content and of the level of intervention of public policies. Porzig (1962) specifies in this respect that "each profession, each circle of interest, has its technical expressions and its own particular ways that must be learned and that, as a result, the outsider, the layman, does not know" (p.219). A joint analysis by the decision-makers and the members of the CAC of the characteristics and of the presentation of the policy evaluated can remedy the problem. It is also insisting on diverse and complementary forms of discussion. The questioning of «test groups » is a additional way to refine the analysis and to understand in further detail the developed scenarios so they may be comprehensible to citizens. A stronger involvement of the citizens thanks to the CAC in the drafting of scenarios is also likely to elicit public participation and to make the public opinion survey a more robust evaluation tool.

But above all, better understanding of the questionnaires and of the scenarios on which these are based gives more credibility to the process in the in itinere phase, by contributing to correct the three main biases of the methodology that discredit its results. The first bias is the difficulty of individuals to place themselves in a hypothetical situation (Hausman, 2012). Ami and Chanel (2009) specify that this difficulty comes from a "lack of experience and information regarding the goods subject to evaluation" (p.49).

It is also the cause of the second bias which is the non-response due to unfamiliarity, or loss of interest shown, by those surveyed and which leads them to answer "I do not wish to respond" or "I do not know, I do not understand". The result of this is a significant loss of accuracy in the information and therefore a loss of relevance in the evaluation. The experts of the National Oceanic and Atmospheric Administration (NOAA), who are a recognised authority regarding the methodology and the application of the CVM, indicate thus in their report entitled "Panel de NOAA" that the results are unreliable if there is an elevated nonresponse rate. Finally, a third bias originating from the surveyor can also affect the results. The surveyors, in a will to be "socially desirable", wishes to present themselves in a favourable light to the respondent. The lack of information from respondents about the goods reinforces the power of influence of the surveyor. These three biases strongly call into question the quality of the results and the unilateral character of the methodological approach of CVM (Boxed Text1). The involvement of the CAC in the different stages of the technical implementation of the CVM is a factor of a reduction in the biases of the survey. 


\section{Boxed Text 1:}

\section{The Biases linked to the administration of hypothetical scenarios destined for citizens}

The ground survey conducted in priority education (Chassy 2014) enabled the study of the understanding of hypothetical scenarios. The choice was made to perform a comparative analysis relying on two different survey methods (telephone $\mathrm{n}=192$ and self administatered $\mathrm{n}=144$ ) during which an identical questionnaire $^{1}$ was administered. The analysis centers on the respondents' behaviour, more specifically on the question regarding the monetary assessment of the program. These questions had the particularity of inviting the respondents to project themselves in a hypothetical situation and to express themselves on the usefulness of the proposed scenario. Did the respondents fully understand the proposed scenario? Did the respondents experience any external influences? Three biases were studied: The non-response bias, the hypothetical bias and the bias linked to the surveyor's presence.

\section{Non response bias and hypothetical bias.}

Table 1

Non response rate on the hypothetical scenario

\begin{tabular}{|c|c|c|c|c|c|c|}
\hline \multirow{2}{*}{ Variables } & \multirow{2}{*}{$\begin{array}{l}\text { NR } \\
\text { (T) }\end{array}$} & \multirow{2}{*}{$\begin{array}{c}\text { \%NR } \\
(\mathrm{T})\end{array}$} & \multirow{2}{*}{$\begin{array}{l}\text { NR } \\
\text { (A) }\end{array}$} & \multirow{2}{*}{$\begin{array}{l}\text { \%NR } \\
\text { (A) }\end{array}$} & \multicolumn{2}{|c|}{$\begin{array}{c}\text { Proportion equality test } \\
\text { (p-value) }\end{array}$} \\
\hline & & & & & $\begin{array}{c}\text { Even } \\
\text { Variances }\end{array}$ & $\begin{array}{c}\text { Uneven } \\
\text { Variances }\end{array}$ \\
\hline \multicolumn{7}{|l|}{$\begin{array}{l}\text { Monetary evaluation } \\
\text { of the program }\end{array}$} \\
\hline Affected by scenario 1 & 11 & 5,73 & 26 & 18,60 & $0,0003 * * *$ & $0,0008 * * *$ \\
\hline Affected by scenario 2 & 6 & & 25 & 17,36 & $0,0000 * * *$ & $0,0000 * * *$ \\
\hline Affected by scenario 3 & 14 & 7,29 & 18 & 12,50 & 0,1081 & 0,1206 \\
\hline Funding scenario 1 & 12 & 6,25 & 12 & 8,33 & 0,4646 & 0,4731 \\
\hline Funding scenario 2 & 5 & 2,60 & 21 & 14,59 & $0,0000 * * *$ & $0,0002 * * *$ \\
\hline Funding scenario 3 & 18 & 9,38 & 20 & 13,89 & 0,1411 & 0,2083 \\
\hline \multicolumn{7}{|c|}{$\begin{array}{l}\text { Note: NR (Non-response) / T (Telephone) / A (Auto). The proportion equality test assumes } \\
\text { that the tested variable variance (non-response variables) is the same for both samples } \\
\text { (regarding both methods). An «improved " version of the test removes this assumption and } \\
\text { allows for a valid test even with uneven variances. In our case, both tests lead to the same } \\
\text { conclusion, that is to say that we also took into account the possibility that variances could be } \\
\text { uneven. The difference is not significant if the probability is higher than } 10 \% \text {. }\end{array}$} \\
\hline
\end{tabular}

\section{- Interpretation}

The non-response rate is higher on questions about the monetary assessment of the program. These questions have the particularity of inviting the respondents to project themselves in a hypothetical situation and to express themselves on the usefulness of the proposed scenario. A difference between the two modes of interrogation is observed. Respondents in an "selfadministered " survey have more difficulties to answer these types of questions despite having more time to familiarise themselves with the questionnaire. One extra element reinforces this result: some mentioned - when handing the questionnaire back - that they answered it with other people in order to gain a better understanding of the questions asked of them.

\section{Surveyor bias}

Table 2 Surveyor bias (telephone survey) on the hypothetical scenario

\begin{tabular}{lcc}
\hline \multicolumn{1}{c}{ Variables } & Fisher's exact test \\
\hline Monetary evaluation of the program & \\
Affected by scenario 1 & 0,121 & $*$ \\
Affected by scenario 2 & 0,061 & $* * *$ \\
Affected by scenario 3 & 0,006 & $* * *$ \\
Funding scenario 1 & 0,007 & $* * *$ \\
Funding scenario 2 & 0,004 & $* * *$ \\
Funding scenario 3 & 0,004 \\
\hline Note: Fisher's exact test can be used on contingency tables of low numbers in order to
\end{tabular}

Note: Fisher's exact test can be used on contingency tables of low numbers in order to test the independence of two qualitative variables. For each question asked (opinions),
it allows here to test the independence between the answers (yes or no) and the variable identifying the surveyor (A, B, C, D, E, F). We are showing in this table the probability of wrongly rejecting the independence hypothesis.

\section{- Interpretation}

Significant variables are noticed in the monetary assessment of the program. However, at this stage in the observation, one cannot talk about a surveyor presence linked bias. Differences in response frequency are observed between samples collected by different surveyors. The most plausible interpretation is that, in front of the surveyor, respondents received help to answer some of the questions. To confirm this interpretation, we tried to underline surveyor-linked over/underrepresentation (below). Some surveyors yield more support for some of the variables which indicates that surveyors influence the answers given by the respondents during the telephone survey.

\section{Table 3}

Surveyor bias (over/under representation) on the hypothetical scenario

\begin{tabular}{|c|c|c|c|c|c|c|}
\hline \multirow{2}{*}{ Variables } & \multirow{2}{*}{$\begin{array}{c}\text { Fisher's exact } \\
\text { test }\end{array}$} & \multicolumn{5}{|c|}{ Surveyor } \\
\hline & & A $\mathbf{B}$ & C & D & E & $\mathbf{F}$ \\
\hline \multicolumn{7}{|c|}{ Monetary evaluation of the program } \\
\hline \multicolumn{7}{|c|}{ Affected by scenario 1} \\
\hline Affected by scenario 2 & 0,061 & + & & & & \\
\hline Affected by scenario 3 & 0,006 & + & - & & & \\
\hline Funding scenario 1 & 0,007 & & - & & + & - \\
\hline Funding scenario 2 & 0,004 & + & & - & + & - \\
\hline Funding scenario 3 & 0,004 & + & - & & + & - \\
\hline \multicolumn{7}{|c|}{$\begin{array}{l}\text { Note: For each variable where Fisher's exact test is significant, a calculation of under/over } \\
\text { representation was realised. (The }+ \text { sign indicates that the surveyor received more acceptation } \\
\text { than normal, the - sign is the opposite). The }+ \text { or }- \text { signs indicate the values observed for the } \\
\text { chi } 2 \text { contributions when these are « high } \text {. The sign being the one of the difference between } \\
\text { the value of the cell and the expected value if independence was present (product of the } \\
\text { margins divided by the total size of the table). }\end{array}$} \\
\hline
\end{tabular}

\section{Summary of principal biases in the understanding of hypothetical scenarios}

The presence of a non-response bias and of a surveyor linked bias leads us to say that the hypothetical scenario was not always easy to understand during the telephone survey as well as during the self-administered survey. There is therefore a hypothetical bias that is « a black spot » of the method.

These methodological issues, observed in our model, match correspond to the ones expressed by Flachaire and Hollard (2005): The method "does not leave enough time for a significant learning" (p.9) to understand the contents of the scenario.

\footnotetext{
${ }^{1}$ Questionnaire - Survey on social and economical utility of sociocultural activities developed within the framework of the local education policy for children and young people.
} 
Finally, at the last stage, ex post, of the evaluation, the involvement from citizens is also essential, with respect to reaching final decisions on effective implementation or on adjustments of the programs. A contingent valuation adequately put into place beforehand, in accordance with the previous principles, must result in decisions that often prove to be difficult to take by public decision-makers, particularly in a multi-level system. Indeed, decision-makers react differently to the results obtained depending on their political leanings, their areas of competence and their territorial position. In this respect, Bance and Chassy (2016) stated that certain decision-makers run important risks (for example concerning their re-election) by taking a final decision based solely on results coming from questionnaires of the CVM. Other decision-makers, on the contrary, can find in the simple transposition the opportunity to strengthen their own positions, their political interests and their prerogatives in relation to their partners. The sources of disagreements on shared decision-making are real under these conditions and the CAC may look like useful mediators to reach the final decision. The CAC can also provide feedback to know if the planned decisions are likely to have important political repercussions and if results from the evaluation remain reliable. Citizens'perspectives are indeed actually potentially fickle. Sheatsley and Hyman (1953) stipulate on this subject that the Human acts depend upon case-specific factors. The hype surrounding projects and the alternatives that emerge can in this way modify opinions after multi-level decision-makers have formalised them after the evaluation process.

The transmission of the results from the evaluation process to the members of the CAC for a critical examination of the conditions and limitations of the implementation would be from then on a current source of information or even of revised opinions. Decision-makers could analyse the degree of satisfaction of the members of the CAC, in case of arising opposition emerges or preoccupations as to the views of the decision-makers following the evaluation.

This feedback could be the basis for a discussion with the players on the ground about the values and purpose of public policies. This would place public authorities as « orchestra conductors » who finalise the decision based upon the weaknesses and the strengths arising from the discussion with the civil society actors. Out of this repeated process, compromises based on shared results could emerge.

\section{Conclusion}

This article offers deeper consideration in an attempt to develop, as recommended by Portney $(1994,15)$, "an improved theory of preference and choice "and to do this recommends the mobilization of the CVM of CAC. However, our study places the approach in a new framework which is that of a system of multi-level governance. It highlights the difficulty that exists in evaluating public policy through the use of traditional methods of the CVM. The CVM remains a tool in multi-level systems allowing, on the basis of CBA, various public decision-makers to jointly bring arbitration procedures to produce public goods. It provides useful information on the needs of citizens and thus facilitates dialogue and exchange of information. But the traditional approach, centralist, shows serious limitations at the methodological level. In fact, citizens are hardly involved in the different steps of its implementation, whether it is ex ante, in itinere and ex post, a situation which fundamentally reduces its relevance in a multi-level system grants importance to the proximity of its citizens. Faced with a multiplicity of actors, new methods in the deployment of evaluation processes and of decision-making prove therefore necessary. It has been shown that the involvement of CAC at each step of the process provides elements of information and dialogue useful in order to noticeably improve the efficiency of the evaluation process. The adoption of the 
methodology presented allows us, however, to provide some answers to the problems of the hypothetical bias of CVM put forward by Hausman (2012).

The mobilization of CAC that we recommend avoids the citizens-consumer "essentially inventing their answers on the fly" (Hausman, 2012, 43). The CACs are indeed tools permitting respondents to better understand questionnaires and to express themselves with full knowledge of the facts. They will therefore bring more sincere and thoughtful responses and therefore be more reliable. The CAC also contribute to adopting or adjusting the programs in the system of multi-level governance with real feedback from the citizens after the responses to the CVM questionnaires. In other terms, it contributes to place CVM in a wide participative plan and to adapt the decision-making process ex post in a multi-level system. This multidimensional evaluation process, mobilising the CVM and the CAC, can be seen as an ideal-type approach for public consultation, through the special care that is brought to the expression of the civil society's wishes in the operating stages the evaluation. However, the methodology can appear costly and complex to establish due to the diversity and the large number of actors that it would be advisable to involve. Nevertheless, it is possible to remove some of its limitations. A lot can be learnt from the local dynamics of actors, and from participative approach started by pre-existing associations or citizens' committees or consumer groups. This allows on the one hand to mobilize the citizens more effectively by relying on their collective experience, and on the other hand, to benefit from their knowledge on the ground. Of course, this should not prevent from looking at including other citizens likely to bring relevant information regarding the policies evaluated. These analytical leads open, in any case, the way to new studies aiming to further detail how CAC should be formed and organised so that they may be efficient tools to relay the preferences of the citizens and tools of joint-construction via the path of discussion of public policy programs in a multi-level system. 


\section{References}

Ami, D., Chanel, O. (2009). Vers un renouveau encore fragile des méthodes de préférences déclarées. Economie et Statistique, n ${ }^{\circ}$, pp. 47-51.

Arrow, K.J., Solow, R., Portney, P.R., Leamer, E.E., Radner, R., Schuman, H. (1993). Report of the NOAA Panel on Contingent Valuation. Registre Federal 4601- 4614.

Bailly, J.P. (1998). Prospective, débat, décision publique. Journal Officiel, nº 6, pp. 1-123.

Bance, P. (2016). L'État stratège : État « réduit» ou à «capacité étendue » en régime de gouvernance multi-niveaux. In P. Bance, Quel modèle d'État stratège en France ? Presses Université de Rouen et du Havre.

Bance, P., Chassy, A. (2016). Opportunités et limites de la Méthode d'Évaluation Contingente en régime de gouvernance multi-niveaux. Revue Française d'Economie, vol. XXXI, pp. 93124.

Brandenberger, A.M., Nalebuff, B.J. (1996). Co-opetition. Currency.Doubleday, New York.

Blondiaux, L. (1997). Ce que les sondages font à l'opinion publique. Politix, vol.10, pp.117136.

Bonnieux, F. (1998). Principes, mise en œuvre et limites de la méthode d'évaluation contingente. Revue de l'Institut d'Économie Publique, n 1 , pp. 47-89.

Bourdieu, P. (1973). L'opinion publique n'existe pas. Les Temps Modernes, $\mathrm{n}^{\circ}$ 318, pp.12921309.

Bourdin, J., André, P., Plancade, J.P. (2004). L'évaluation des politiques publiques en France. Sénat, n³92, pp. 1- 416.

Carson, R.T. (2012). Contingent Valuation : A Pratical Alternative when Prices Aren't Available. Journal of Economic Perspectives, vol. 26, pp.27-42.

CEEP-CIRIEC. (2000). Services of General Economic Interest in Europe. Regulation, Financing, Evaluation, Good Practices. Study carried out with the support of the European Commission - DG Employment and Social Affairs.

Chassy, A. (2011). L'évaluation par l'approche participative : un remède à la crise des services publics. In Bance, P., Bernier, L., (dir.), Contemporary Crisis et Renewal of Public Action. Towards the Emergence of a New Form of Regulation. Peter Lang, Bruxelles.

Chassy, A. (2014). Application de la méthode d'évaluation contingente aux politiques éducatives territorialisées. Thèse pour le Doctorat ès Sciences économiques : Université de Rouen.

Christiansen, T. (1996). Restructuring European Space: From Territorial Politics to Multilevel Governance. EUI. Work. Paper. (96-53).

Ciriacy-Wantrup, S.V. (1947). Capital Returns from Soil-Conservation Practices. Journal of Farm Economics, n 29, pp.1181-1196.

Claeys-Mekdade, C., Vivien, F.D. (2003). Economie et démocratie dans le domaine de l'environnement: la méthode d'évaluation contingente en question. In H. Guillemin, H. Jorda, et M. Pouchol (dir.), La démocratie et le marché, Economie et Démocratie. L'Harmattan, Paris. 
Clinch, J.P., Murphy, A. (2001). Modelling Winners and Losers in Contingent Valuation of Public Goods: Appropriate Welfare Measures and Econometric Analaysis. Economic Journal, vol.111, pp. 420-443.

Colson, F, Stenger-Letheux, A. (1995). Évaluation monétaire des avantages environnementaux de l'agriculture : une analyse coût-bénéfice appliquée à la gestion des espaces et des paysages agricoles dans le cadre de la nouvelle PAC. La Documentation Française, Paris.

Davis, R.K. (1963). Recreation Planning as an Economic Problem. Natural Resources Journal, $\mathrm{n}^{\circ}$ 3, pp. 239-249.

Delebarre, M. (1998). L'évaluation au cœur des enjeux de l'administration publique française. Pouvoirs Locaux, $\mathrm{n}^{\circ}$ 38, pp.105-107.

Diamond, P.A. Hausman, J.A. (1993). On Contingent Valuation Measurement of Non-use. In Hausman, J., (Ed.), Contingent Valuation: A Critical Assessment. Amsterdam, North Holland Press, pp. 3-38.

Faburel, G., Leroux, M., Colbeau-Justin, L. (2000). Observation de l'acceptabilité institutionnelle et sociale d'une modalité d'expertise appliquée aux transports. EIL/PREDIT, pp. 3-101.

Favre, P., Hayward, J., Schemeil, Y. (2003). Etre gouverné, Etudes de cas en l'honneur de Jean Leca. Presses de la Fondation Nationale des Sciences Politiques, Paris.

Flachaire, E., Hollard, G. (2005). Une approche comportementale de l'évaluation contingente. Revue Economique, vol. 57, pp.315-329.

Grappey, C. (1999). Fiabilité des résultats de méthode d'évaluation contingente. Économie rurale, $\mathrm{n}^{\circ} 254$, pp. $45-53$.

Hausman, J. (2012). Contingent Valuation: From Dubious to Hopeless. Journal of Economic Perspectives, vol. 26, pp. 43-56.

Harrison, G.W. (2002). Contingent valuation meets the experts : a critique of the NOAA. Panel Report. Paper presented at the Second World Congress of Environmental and Resource Economists. Monterey CA: AERE; EAERE, June.

Jakobsen, M., James, O., Moynihan, D, Nabatchi, T. (2016). JPART Virtual Issue on CitizenState Interactions in Public Administration Research. Journal Public Administration Research Theory, vol.1.

Loeper, A. (2017). Cross-border externalities and cooperation among representative democracies. European Economic Review, vol. 91, pp.180-208.

Meunier, V., Mardsen, E. (2009). L’Analyse Coût-Bénéfices, guide méthodologique. Collection Cahier Securité Industrielle, $\mathrm{n}^{\circ} 6$.

Mignauw, T. (2016). La contestation des grands projets et l'exercice de la démocratie : l'État stratège en question? In P. Bance (dir.), Quel modèle d'État stratège en France ? Presses Universitaires de Rouen et du Havre.

Milet, H. (2007). L'intervention des citoyens dans le processus d'évaluation. In J. Jacot, A. Fouquet (dir.), Le citoyen l'élu, l'expert. L'Harmattan, Paris.

Mitchell, R.C. Carson, R.T. (1989). Using Surveys to Value Public Goods: The Contingent Valuation Method. Resources for the Future, Washington D.C. 
Ostrom, V., Tiebout, C.M., Warren, R. (1961). The Organization of Government in Metropolitan Areas: a Theoretical Inquiry. The American Political Science Review 55, (Issue 4), pp.831-842.

Phanuel, D., Assens, C. (2000). Harmonisation des intérêts individuels et collectifs dans une municipalité. 2ème colloque pluridisciplinaire sur la décision, Troyes, 7-8 décembre 2000, publiée dans les Actes, ${ }^{\circ} 1$, pp. 65-77.

Plottu, B., Plottu, E. (2009). Contraintes et vertus de l'évaluation participative. Revue Française de Gestion 2, n 192, pp. 31-58.

Portney, P.R. (1994). The Contingent Valuation Debate: Why Economists Should Care. Journal of Economic Perspectives, vol. 8, pp. 3-17.

Porzig, W. (1962). Probleme, Methoden und Ergebnisse der modernen Sprachwissenschaft. A. Francke, Suisse, Bern, München.

Randall, A., Ives, B., Eastman, C. (1974). Bidding Games for Valuation of Aesthetic Environmental Improvements. Journal of Environnental Economics and Management, vol. 1, pp. 132-149.

Roy, B., Damart, S. (2000). L'analyse Coûts-Avantages, outil de concertation et de légitimation. Métropolis, n 108-109, pp.1-16.

Ryan, M., Scott, D.A., Reeves, C., Bate, A., Van Teijlingen, E.R., Russell, E.M., Napper, M., Robb, C.M. (2001). Eliciting public preference for the healthcare a systematic review of techniques. Health Technology Assessment, vol.5, pp. 1-186.

Sheatsley, P.B., Hyman, H.H. (1953). Les enquêtes sur l'opinion publique et la prévision du comportement. Bulletin International des Sciences Sociales, vol. V, pp. 497-705.

Sintomer, Y. (2008). Du savoir d'usage au métier de citoyen. Raisons Politiques, vol. 3, pp. 115-133.

Terreaux, J.P., Brahic, E. (2009). Évaluation économique de la biodiversité. Quae, Paris.

Voltaire, L., Nassiri, A., Bailly, D., Boncoeur, J. (2011). Effet d'une taxe et d'un droit d'entrée sur les consentements à payer des touristes pour de nouvelles réserves naturelles dans le golfe du Morbihan. Revue Etudes en Agriculture et Environnement, vol. 92, pp.183-209.

\section{Other documents}

Conseils de Citoyens : Cadre de référence, Ministère des Droits des Femmes de la Ville, de la Jeunesse et des Sports, site internet: http://www.ville.gouv.fr/IMG/pdf/cadre-de-referenceconseils-citoyens.pdf

Correctional Service Canada «Working together », Citizen Advisory Commitees the Service of canada, Website : http://www.csc-scc.gc.ca/cac/092/dep-eng.pdf 